\title{
Designing innovative productive cropping systems with quantified and ambitious environmental goals
}

\author{
Caroline Colnenne-David ${ }^{1 *}$ and Thierry Doré ${ }^{2}$ \\ ${ }^{1}$ INRA, UMR 211 Agronomie, 78850 Thiverval-Grignon, France. \\ ${ }^{2}$ AgroParisTech, UMR 211 Agronomie, 78850 Thiverval-Grignon, France. \\ ${ }^{*}$ Corresponding author: caroline.colnenne@grignon.inra.fr
}

\begin{abstract}
Agriculture must face a number of very pressing environmental issues. We used the prototyping method to design three innovative cropping systems, each satisfying three ambitious goals simultaneously: (1) overcoming a major environmental constraint, which represents a major break regarding objectives to be reached in current cropping systems (differing between systems: a ban on all pesticides but with chemical nitrogen $(\mathrm{N}$ ) fertilizer permitted; reducing fossil energy consumption by $50 \%$; or decreasing greenhouse gas (GHG) emissions by 50\%), (2) meeting a wide range of environmental criteria and (3) maximizing yields, given the major constraint and environmental targets. A fourth cropping system was designed, in which the environmental and yield targets were achieved with no major constraint (the productive high environmental performance cropping system (PHEP) system). The performances of these innovative cropping systems were compared to a conventional system in the Ile-de-France region. We used a three-step prototyping method: (1) new cropping systems were designed on the basis of scientific and expert knowledge, (2) these system prototypes were assessed with tools and a model (ex ante assessment) adjusted to the set of constraints and targets, with optimization by an iterative process until the criteria were satisfied and (3) evaluation in a long-term field experiment (ex post assessment), which is currently underway. We describe only the first two steps here, together with the results of the prototypes assessment with tools and a model. The pesticide, energy and GHG constraints were fulfilled. All these innovative systems satisfied environmental criteria in terms of nitrogen and phosphorus management, pesticide use, energy consumption and crop diversity. For the pesticide-free system, the soil organic matter indicator was lower than expected due to frequent plowing (every 2 years) and yields were $20-50 \%$ lower than for the PHEP system, depending on the crop considered. We focus our discussions on the design methodology and the availability of scientific knowledge and tools for projects of this type.
\end{abstract}

Key words: innovative cropping systems, environmental goals, ex ante assessment

\section{Introduction}

Agriculturalists are faced with challenges relating to very pressing environmental and health issues, including the need to decrease pesticide use. In many countries, high levels of pesticides have frequently been found in rivers, lakes and groundwater ${ }^{1,2}$. A second pressing environmental issue is the consumption of fossil fuel. Energy use has markedly increased over the past decade ${ }^{3}$, and some scientists agree that oil availability will decline in the near future $^{4}$, leading to a sharp increase in oil prices ${ }^{5}$. In this context, new ways of optimizing or reducing energy use have been proposed ${ }^{6}$. Global warming is a third challenging environmental issue facing agriculture. About $12 \%$ of global greenhouse gas (GHG) emissions emanate from agricultural lands ${ }^{7}$, and this proportion is expected to rise in the future, due to increases in the amount of land used for agricultural purposes and the intensification of agricultural practices ${ }^{8}$. Carbon (C) sequestration in the soil, through the return of crop residues, root deposition and organic amendments, may help to decrease GHG emissions ${ }^{9}$. Sustainable development is another pressing social issue. Sustainable agriculture must satisfy environmental criteria ${ }^{10}$. The harmful impact of agriculture on the environment can be lessened by optimizing fertilization (N, P) and increasing crop diversity. Currently pesticide use and energy consumption should also be reduced $^{1,2}$, and soil fertility should be maintained. Since the 
1950s, alternative crop management systems have been proposed $^{11}$ and legislation and inspection services have controlled the use of inputs (pesticides, $\mathrm{N}$ fertilization). Finally, agricultural production must satisfy the food needs of a soaring world population ${ }^{10}$. Global agricultural production currently feeds a population of approximately 7 billion. Current projections suggest that the world population will have reached 9 billion by $2050^{12}$. The resulting increase in the need for land for housing will reduce the amount of land available for agricultural purposes $^{13}$. The availability of arable land per capita differs greatly between regions (e.g., between China and South America), and major cropping systems must take this scarcity into account. Foley et al. ${ }^{14}$ have suggested that feeding a population of this size will be possible only if agricultural systems change, along with human eating habits.

Many studies in recent years have focused on the design and assessment of new cropping systems. New crop management strategies have been proposed to decrease pesticide use ${ }^{15}$, to decrease energy consumption ${ }^{16}$, or to enhance $\mathrm{C}$ sequestration through crop management practices ${ }^{17}$. Energy use and GHG emissions have been calculated and assessed for different systems ${ }^{18}$. At the cropping system level, long-term trials have also been set up to investigate the effects of different technical operations, such as $\mathrm{N}$ fertilization, on soil physical and chemical properties ${ }^{19}$ and on soil biology ${ }^{20}$. Several studies have assessed the differences between organic, integrated and conventional cropping systems in terms of $\mathrm{C}$ sequestration ${ }^{21}$, energy efficiency and use ${ }^{22}$, profitability $^{23}$ or productivity ${ }^{24}$. Some authors have analyzed the impact of different degrees of tillage on productivity ${ }^{25}$ or biological activity ${ }^{26}$. Others have focused on the effect of cropping systems on biodiversity ${ }^{27}$, or have used life cycle assessment methods to analyze the sustainability of various farming systems ${ }^{28}$. In most of these cases, new cropping systems were designed by modifying a few agricultural practices targeting a single goal (e.g., no chemicals to be used in organic cropping systems; no plowing to increase $\mathrm{C}$ sequestration; more legumes in the rotation to reduce energy consumption; and more inputs to enhance profitability), without considering the other dimensions of sustainability. Despite the evidence that the future of agriculture must address a wide range of issues, no study has designed innovative cropping systems with specific and quantitative objectives covering a broad range of issues.

The objective of our project was to design, by prototyping $^{29}$, innovative cropping systems meeting three quantitative objectives: (1) to satisfy a major environmental constraint, which represents a major break regarding objectives to be reached in current cropping systems (the banning of pesticide use, reducing fossil energy consumption by $50 \%$ or reducing gas emissions by $50 \%$ ); (2) to satisfy a wide range of environmental criteria with specific quantitative targets; and (3) to produce the maximum yield possible given the constraint and the environmental targets. The ultimate aim of this work is to improve arable cropping systems throughout northern Europe. Prototyping was developed to enable agronomists to design, test and improve more sustainable cropping systems ${ }^{29}$. With this approach, newly designed cropping systems could satisfy several of the issues mentioned above and contributed to identifying the weaknesses of cropping systems. System prototypes were assessed with tools and a model (ex ante assessment), with discussion of their potential performances, before their assessment in a long-term field experiment (ex post assessment). We set up this long-term field experiment in 2008, and its results will be published in due course. We focus here on the prototyping and assessment of the cropping system prototypes. We discuss our results in terms of innovative design methodology, the innovation of agricultural practices, the availability of suitable tools, models and crop management, and the yields achievable.

\section{Materials and Methods}

\section{Design method}

The method used for cropping system design was based on the prototyping approach ${ }^{29-32}$, which involves four major steps:

(i) defining and ranking the constraints and targets;

(ii) designing innovative cropping system prototypes on the basis of current knowledge;

(iii) assessments of cropping system prototypes with tools and models adapted for the constraints and targets used, with improvement of the cropping systems (in terms of rotation or crop management aspects) by an iterative process, until satisfaction of the constraints or achievement of results considered the best possible; and

(iv) assessment of the most promising cropping system candidates in a long-term field trial. This practical assessment is currently being carried out in a longterm field experiment, initiated in 2008.

\section{Constraints and targets for innovative cropping systems}

Four different cropping systems with quantified constraints (i.e., conditions that had to be fulfilled), environmental and yield targets, were designed for the agricultural conditions and principal crops of northern France. These constraints and targets were prioritized as follows: an environmental constraint had to be satisfied first; a set of environmental targets then had to be attained, and finally, yield had to be maximized. The quantitative levels of the constraints did not correspond to any regulations and reflected a major break to be reached in current cropping systems. Inclusion of the use of organic fertilizers (manure, compost, etc.), which are currently not 
readily available to many farmers in large areas of western Europe, was not permitted in the design of the cropping systems.

Productive high environmental performance (PHEP) cropping system. No major environmental constraint was placed on this cropping system, which was designed to reach environmental targets. Eleven environmental indicators, according to the INDIGO ${ }^{\circledR}$ tool $^{33}$, were used to assess the effects of the cropping system on groundwater pollution (nitrate and pesticides), crop diversity, energy use and soil quality (organic matter content and phosphorus concentration). To reach environmental goals, all these environmental indicators, calculated over an entire crop rotation sequence, had to have values higher than 7 (graduated scale from 1 to 10$)^{33}$. This system was used as the reference system for comparisons with the other three systems.

No-pesticide (No-Pest) cropping system. This cropping system was subject to a specific pesticide constraint: no pesticide use was tolerated, even using substances (e.g., acetic acid) at levels usually considered acceptable in organic cropping systems. However, inorganic chemical fertilizers were allowed (these fertilizers are not permitted in organic farming systems). This system had to achieve the same environmental targets as the PHEP cropping system.

Low-energy (L-EN) cropping system. This cropping system was subjected to a specific energy constraint: it had to have fossil fuel consumption levels no greater than half those of the PHEP cropping system. It had to reach the same environmental targets as the PHEP cropping system.

Low-GHG (L-GHG) emission cropping system. This cropping system was subject to a specific constraint concerning GHG emissions: its GHG emissions had to be no more than half those of the PHEP cropping system by increasing $\mathrm{C}$ sequestration in the soil and decreasing nitrous oxide $\left(\mathrm{N}_{2} \mathrm{O}\right)$ emissions. It had to meet the same environmental targets as the PHEP cropping system.

For each cropping system, once the constraint had been satisfied and environmental targets had been reached, the combination of agricultural practices giving the highest yields was retained.

\section{Design of the four innovative cropping systems}

The innovative cropping systems were designed from published knowledge, quantitative data from field experiments and individual or group expertise provided by scientists, extension service staff and farmers. For each cropping system, one prototype, consisting of the species in the rotation and the combination of agricultural practices used, was designed. If the constraints were not satisfied, the candidate was modified iteratively (changes to the crops in the rotation or agronomic practices) until they were. At the beginning of the process, a modification of a crop led to a multitude of changes; at the end, changes were only one at a time. When the constraints were satisfied, environmental targets were optimized by an iterative procedure until improvement was observed. Maximum achievable yields were then determined by expert knowledge or from trial results, for the various cropping systems. The candidate cropping systems selected for further assessment in a field experiment were those with the best performances in terms of constraints, environmental targets and achievable yields.

We carefully selected agronomic strategies from previous publications, to satisfy the given constraints. Examples of such strategies ${ }^{7,9,15,17,34-45}$ are presented in Table 1. Current knowledge, based on conventional cropping systems, had to be adapted for innovative cropping systems, and it was necessary to combine strategies. Agronomic strategies were translated into decision rules (as described by Debaeke ${ }^{46}$ ) to meet the requirements of future cropping systems and to cope with the variability of weather and agronomic conditions.

\section{Assessment with tools and a model and fine-tuning of innovative cropping system prototypes}

During the design process, the cropping system prototypes were assessed with various tools and a model, to determine the best ways to satisfy the set of constraints and targets imposed. Direct and indirect non-renewable energy consumption were assessed with the INDIGO ${ }^{\circledR}$ tool (v. 1.9). Direct energy consumption concerned the fuel, lubricants and electricity used to power farm machinery and tractors. Indirect energy consumption concerned the energy used in the manufacture, formulation, packaging and maintenance of inputs, such as machinery, fertilizer or pesticides. The energy outputs of the cropping systems were calculated as the gross energy content of the harvested produce. Energy consumption was calculated on a per hectare basis, per ton of crop product and per calorie produced, over a complete crop sequence.

$\mathrm{C}$ sequestration in the soil was assessed with (1) the Roth C 26.3 model $^{47}$ and (2) the SIMEOS ${ }^{\circledR}$ tool (v. 2010) based on the AMG model ${ }^{48}$. We used climatic data (i.e., monthly mean air temperature, monthly precipitation and monthly open pan evaporation) from a meteorological station located in Grignon (Ile-de-France region, $30 \mathrm{~km}$ west of Paris). The soil characteristics (plow layer, $0-30 \mathrm{~cm}$ ) used to drive simulations were as follows: clay content $20.6 \%$, bulk density 1.4 , initial C content $8 \mathrm{~g} \mathrm{~kg}^{-1}$ dry matter. The expected annual yields were estimated from experimental data obtained under the same conditions (i.e., Ile-de-France region) and adjusted by expert knowledge. These values were used to estimate the expected annual dry matter production of roots and stubble, as described by Van Groenigen et al. ${ }^{49}$. Direct and indirect GHG emissions were estimated with the GES'TIM database ${ }^{50}$. We focused on two main GHGs: $\mathrm{N}_{2} \mathrm{O}$ and carbon dioxide $\left(\mathrm{CO}_{2}\right)$. Direct emissions included $\mathrm{N}_{2} \mathrm{O}$ emissions 
Table 1. Examples of published agronomic strategies and associated practices for achieving specific goals.

\begin{tabular}{lc}
\hline Specific goal & Agronomic management strategies \\
\hline To reduce pesticide use: & To avoid the coincidence of the pest, \\
(Munier-Jolain et al. ${ }^{34} ;$ & disease and weed contamination \\
Aubertot et al. ${ }^{15} ;$ & periods and sensitive stages of crop \\
Chikowo et al. & development \\
& To reduce the density of pests
\end{tabular}

To reduce the impacts of pests, diseases and weeds on crops

To decrease the pool of pathogenic fungi in the soil, diseases and weeds

To maintain beneficial insects

To reduce fossil fuel energy use: (Tonitto et al. ${ }^{36}$; Deike et al. ${ }^{37}$; Nemecek et al. ${ }^{38}$; Fu et al. ${ }^{39}$; Gelfand et al. ${ }^{40}$ )

To enhance $\mathrm{C}$ sequestration in the soil: (Arrouays et al. ${ }^{9}$; Freibauer et al. ${ }^{41}$; Mosier et al. ${ }^{42}$; Beheydt et al. ${ }^{17}$; Smith et al. ${ }^{7}$; Lehuger $^{43}$ ) To reduce $\mathrm{N}_{2} \mathrm{O}$ emissions: (Rochette and Janzen ${ }^{44}$; Pelster et al. ${ }^{45}$ )

To decrease nitrogen leaching
Direct energy: To decrease the use of the most power-consuming farm machinery

Indirect energy: To decrease chemical $\mathrm{N}$ fertilization

To decrease organic matter mineralization

To allow high levels of $\mathrm{C}$ accumulation, depending on the nature of the crop residues

To decrease anaerobic conditions, to decrease denitrification mechanisms

To decrease the amount of available mineral $\mathrm{N}$ in the soil

To decrease soil nitrate content during autumn and winter
Example of agronomic practices

Modification of sowing date, earlier for oilseed rape, later for winter wheat

Use of mechanical weeding

Use of Trichogramma parasitoid wasps against Ostrinia nubilalis on maize

Decrease in sowing density and $\mathrm{N}$ fertilization to decrease shoot biomass

Choice of varieties with the highest resistance

Maximization of competition against weeds, by sowing winter oilseed rape very early (mid-August in the Ile-de-France region)

Lengthening of the crop rotation

Sowing of a wide range of crops, to decrease the pool of fungi in the soil

Maximization of the use of stale seed beds to increase weed emergence before sowing

Shallow plowing to maintain populations of carabid beetles (slug predators)

Reducing or eliminating the use of deep plowing

Introduction of large numbers of legumes and species with the highest $\mathrm{N}$ use efficiency into the crop rotation

Avoidance of plowing, replaced by direct drilling (conversion to no-tillage practices)

Sowing of maize and cereals in rotation

Decreasing compaction and soil moisture content without deep tillage

Optimization of $\mathrm{N}$ fertilization, according to soil nitrogen content

Increasing the $\mathrm{N}$ use efficiency of crops

Sowing of catch crops

Sowing of oilseed rape after legumes

Banning of $\mathrm{N}$ fertilization during autumn and winter from $\mathrm{N}$ fertilizers, calculated with Intergovernmental Panel on Climate Change coefficients ${ }^{51}$, and the $\mathrm{CO}_{2}$ produced by the combustion of fossil fuels by farm machinery; $\mathrm{CO}_{2}$ respired by soil organisms was not taken into account in calculations. Indirect emissions corresponded to the use of fossil energy in the manufacture and maintenance of farm inputs. GHG balances (C sequestration plus GHG emissions) were determined over periods of 25 and 50 years, in accordance with Intergovernmental Panel on Climate Change proposals ${ }^{51}$ and current knowledge of $\mathrm{C}$ sequestration kinetics in the soil. In this investigation, any GHG entering the system is counted negatively whereas GHG leaving the system is counted positively. Therefore, the overall balance is a positive value if more GHGs are emitted than sequestered in the system.

Environmental indicators, such as in the INDIGO $^{\circledR}$ tool (v. 1.9), were used to assess the environmental effects of cropping system prototypes. Three indicators of nitrogen effects provided information about ammonia volatilization, $\mathrm{N}_{2} \mathrm{O}$ emissions into the air, and nitrate leaching into the groundwater. Four pesticide indicators were studied: three providing information about pesticide volatilization, pesticide runoff and pesticide leaching into groundwater and one taking the global effect of pesticides into account. The final four indicators provided information about crop diversity, energy consumption, organic matter in the soil and phosphorus management. Each indicator takes a value between 1 (worst) and 10 (best). For rotations of more than five crops, the crop diversity indicator was calculated from the coefficients of Leteinturier ${ }^{52}$. For example, values $0.5,4.1$ and 7.6, respectively, correspond to a wheat monoculture, a wheat-maize rotation and a wheat-sunflower-spring barley-maize rotation.

All these tools and the model were chosen on the basis of their relevance for assessing compliance with constraints and environmental targets. In a comparison of the 
performance of nine soil organic $\mathrm{C}$ models, using different datasets from long-term experiments from different parts of the world, Smith et al. ${ }^{53}$ found that the Roth C model was among those that performed best. Bockstaller et al. ${ }^{54}$ analyzed four methods for assessing the sustainability of agricultural systems. They found that the INDIGO ${ }^{\circledR}$ tool was the most relevant for conditions corresponding to those used here. These tools and the model have been regularly used in different countries. For example, Roth $\mathrm{C}$ has been used by Liu et al. ${ }^{55}$ and Cerri et al. ${ }^{56}$, and INDIGO $^{\circledR}$ has been used by Bockstaller et al. ${ }^{54}$.

\section{Current cropping system in the lle-de-France region}

The current system in the Ile-de-France region was defined on the basis of data collected in 2006 (Agreste ${ }^{57}$ ), the most recent data available at the initiation of this program. We defined the current cropping system in terms of agronomic practices and crop descriptions. This system was validated by various experts (farmers, extension service staff) with few adjustments in terms of types and numbers of crops in the rotation. This system was used as a reference for further comparisons.

\section{Results}

\section{Design methodology step}

The systems were designed over a 6-month period, by a panel of about 15 experts. For each innovative cropping system, the first candidate characteristics were based on the current cropping system in the Ile-de-France region. The system was then optimized through an iterative process, which produced approximately 70 prototypes, to find the four most promising candidates. These candidates corresponded to the prototypes satisfying the constraint and environmental targets imposed and yielding the best results in the assessment. For example, for the PHEP system, the value of the crop diversity indicator was gradually increased from 5 to 7 during the fine-tuning of the system, with simultaneous improvement of the values of the other indicators. The first prototype was based on a 3-year rotation (winter oilseed rape, winter barley and winter wheat), currently used in the Ile-de-France region. In the best prototype, a winter legume and spring barley with a mustard catch crop were gradually introduced, leading to the following rotation: winter field beans (Vicia $f a b a$ ), winter wheat, winter oilseed rape, winter wheat and spring barley with a mustard catch crop. In the design process, we began by determining the crop rotation and then defined the crop management practices.

\section{Description of the innovative cropping system prototypes}

For each cropping system, we present only the most promising prototype. The systems are first described in terms of the crop rotation, crop management practices and yield targets. We then present the results of the final assessment with respect to constraints (i.e., pesticide use, energy consumption and GHG emissions) and, finally, we evaluate the systems in terms of environmental targets. The crop rotations and targeted yields are presented in Tables 2 and 3.

The productive PHEP. The PHEP cropping system was designed with multiple environmental targets in mind and was based on the following agronomic strategies: (1) to reduce pesticide use, we increased crop diversity (four different crops instead of the three currently sown); (2) to reduce the amount of $\mathrm{N}$ used and indirect energy consumption, we included at least one legume in the rotation; (3) to decrease nitrogen leaching, a catch crop was always sown before the spring crop and $\mathrm{N}$ fertilization was forbidden during autumn and winter; (4) to reduce direct energy consumption, plowing was allowed only once in the rotation, before the spring crop; (5) to reduce pesticide use and crop loss due to insects and diseases, highly resistant varieties were used, together with optimal sowing dates and densities; and (6) to stabilize or/and to enrich the soil organic matter (SOM) content of the soil, crop residues were not removed. As the system had to satisfy environmental targets requiring the use of fewer inputs, the target yields set were similar to those currently achieved with low-input cropping systems in the Ile-deFrance region.

The No-Pest cropping system. Pesticide use was prohibited in the 'No-Pest' cropping system. Therefore, this cropping system was designed as follows: (1) to break the cycles of some common soil-borne pathogens, we used a long rotation including a range of species (five different crops), with the alternate sowing of host and non-host plants; (2) to reduce weed emergence from year to year, we sowed species with different sowing dates in spring and in winter successively; (3) to decrease pest and disease pressure and damage, we used highly resistant varieties and species mixtures, and excluded crops highly susceptible to some enemies but with few non-chemical solutions, such as oilseed rape or potatoes, from the rotation; (4) to increase the competitiveness of the crop with respect to weeds, we sowed species with rapid shoot growth, such as hemp and triticale; (5) to maximize weed emergence before sowing, we used the stale seed-bed technique; (6) to reduce weed emergence after sowing, plowing was carried out before each spring crop; and (7) we adapted sowing densities to make it possible to use mechanical weeding techniques and to decrease pathogen propagation. We used the following approaches to reach environmental targets: (1) to reduce nitrate leaching, catch crops were always sown before spring crops and the spreading of nitrogen fertilizer was allowed only in the spring; (2) to decrease direct and indirect energy consumption, we decreased the number of plowing events and $\mathrm{N}$ fertilization was calculated according to yield objectives; and (3) to stabilize SOM, crop residues were 
Table 2. Crop rotations of the innovative cropping systems designed, and a current cropping system, defined by experts on the basis of data from the Ile-de-France region in 2006 (Agreste ${ }^{57}$ ).

\begin{tabular}{|c|c|}
\hline Cropping system & Crop rotation \\
\hline PHEP & $\begin{array}{l}\text { Winter field bean-Winter wheat—Winter oilseed rape-Winter wheat—-(with mustard as a catch crop)- } \\
\text { Spring barley }\end{array}$ \\
\hline No-Pest & $\begin{array}{l}\text { Triticale-(species mixture as a catch crop) Maize-Winter wheat-(species mixture as a catch crop) Spring } \\
\text { field bean-Winter wheat-(species mixture as a catch crop)-Hemp }\end{array}$ \\
\hline L-EN & $\begin{array}{l}\text { Winter field bean-Winter wheat-Winter oil flax-Winter wheat-white clover mixture - (white clover as a } \\
\text { catch crop) Spring oat }\end{array}$ \\
\hline L-GHG & $\begin{array}{l}\text { Triticale - (frost-sensitive species mixture as a catch crop) - Spring field bean-Winter oilseed rape } \\
\text { (volunteers)-Winter wheat-(legumes as a cover crop)-Winter barley_-(legume-oat mixture as } \\
\text { catch crop) Maize }\end{array}$ \\
\hline Ile-de-France (IdF) & Winter oilseed rape —Winter wheat_-Winter barley_-Maize —Winter wheat_-Winter wheat \\
\hline
\end{tabular}

Table 3. Targeted yields $\left(\mathrm{t} \mathrm{ha}^{-1}\right)$ for different species sown in the innovative cropping systems and comparison with current yields. Cropping systems: PHEP (productive high environmental performance), No-Pest (no-pesticide use), L-EN (low-energy use), L-GHG (low-greenhouse gas emissions) and IdF (current system in Ile-de-France region).

\begin{tabular}{lccccl}
\hline Cropping systems/crops $\left(\mathbf{t h a}^{-\mathbf{1}}\right.$ ) & PHEP & No-Pest & L-EN & L-GHG & IdF mean from 1998 to 2007 (Agreste) \\
\hline Spring barley & 6.2 & - & - & - & - \\
Winter barley & - & 4.6 & - & 6.6 & 6.6 \\
Spring field bean & - & 4.7 & - & 4.7 & - \\
Winter field bean & 3.4 & - & 3.4 & & - \\
Hemp & - & 8 & - & - & - \\
Maize & - & 7.3 & - & 9.1 & 9.1 \\
Winter oil flax & - & - & 1.8 & - & - \\
Winter oilseed rape & 3.1 & - & - & 3.1 & 3.4 \\
Triticale & - & 4.2 & - & 6.1 & - \\
Winter wheat & 7.9 & 5.5 & 6.3 & 7.9 & 8.0 \\
\hline
\end{tabular}

not removed. Yield targets were lower than those for the PHEP cropping system, because no pesticides were used. However, they were higher than those achieved in organic systems because chemical fertilizers were allowed, increasing flexibility in the management of crop nitrogen nutrition. For the integration of these features, in accordance with current knowledge of pest and disease pressures in the Ile-de-France region, experts suggested yield potentials 30\% lower than those for the PHEP system for cereals and $25 \%$ lower for field beans.

L-EN cropping system. The L-EN cropping system was designed, to have a much lower energy consumption than the PHEP cropping system, as follows: (1) to reduce indirect fuel consumption due to $\mathrm{N}$ fertilization, we included as many legumes as possible in the rotation (field beans as a main crop, clover as a catch crop and a white cloverwinter wheat mixture), and we used species or varieties with high $\mathrm{N}$ use efficiency (e.g., oats ${ }^{58}$ ) and forms of mineral $\mathrm{N}$ fertilizers requiring less energy for their manufacture; (2) to decrease direct fuel consumption, we omitted plowing, which is a very resource-intensive operation, and used a direct drilling system; and (3) we decreased the amounts of mineral fertilizer (N, P and $\mathrm{K}$ ) applied, implying a decrease in target yields. We also designed the L-EN cropping system along the same lines as the PHEP system, to achieve environmental targets for crop diversity, length of rotation, date of nitrogen spreading and catch crop sowing. Target yields were 20\% lower than for the PHEP cropping system, except for field beans.

L-GHG emission cropping system. The L-GHG cropping system was designed to decrease GHG emissions by increasing $\mathrm{C}$ sequestration in the soil and decreasing $\mathrm{N}_{2} \mathrm{O}$ emissions.

C sequestration in the soil was increased by: (1) including as many cereals as possible in the rotation, to ensure the production of large amounts of residues (i.e., maize, winter wheat, winter barley or triticale); (2) maintaining continuous soil cover to increase the amounts of organic residues (i.e., cover or catch crops were always sown between main crops, and volunteers were left to grow after harvest); (3) targeting high yields for the main and catch crops, to ensure the production of large amounts of residues; and (4) excluding moldboard plowing, which increases $\mathrm{C}$ mineralization.

$\mathrm{N}_{2} \mathrm{O}$ emissions were reduced by: (1) decreasing the amount of $\mathrm{N}$ fertilizer required at rotation scale ${ }^{59}$, and consequently direct emissions of $\mathrm{N}_{2} \mathrm{O}$, by sowing legumes in the rotation (main and catch crops); (2) improving and optimizing $\mathrm{N}$ fertilization practices according to climatic conditions, through the use of appropriate decision rules 
to prevent applications in conditions favoring $\mathrm{N}_{2} \mathrm{O}$ emissions; and (3) sowing species with taproots to reduce soil compaction and $\mathrm{N}_{2} \mathrm{O}$ emissions.

The L-GHG cropping system was also designed according to the same principles as the PHEP system, to reach environmental targets for crop diversity, length of rotation, pesticide use, date of $\mathrm{N}$ spreading and catch crop sowing. Target yields were considered to be a compromise between the production of large amounts of $\mathrm{C}$ residues (i.e., high yields) and the decrease in $\mathrm{N}_{2} \mathrm{O}$ emissions (i.e., low $\mathrm{N}$ fertilization). Experts thought that potential yields would be similar to those achieved by the PHEP cropping system.

The current cropping system in the Ile-de-France region. This system is based on a cereal crop rotation, with five cereal crops over a 6-year rotation (Table 2). To secure high yields, the agronomic practices were as follows: regular plowings, four times over a 6-year rotation. The amounts of $\mathrm{N}$ fertilizer exceed crop requirements, to prevent yield shortfalls in the event of unfavorable climatic conditions or unexpected nitrogen losses. Pesticides and growth regulators were used liberally to prevent diseases, weeds, pests and lodging (three to five pesticides every year).

\section{Cropping System Prototypes Assessments with Tools and a Model}

\section{Constraint assessment}

Pesticide constraint in the No-Pest cropping system. This constraint was achieved by not applying pesticides in the No-Pest cropping system.

Energy constraint in the L-EN cropping system. Mean total fossil energy consumption (direct and indirect energy), calculated over a single rotation, was $4517 \mathrm{MJ} \mathrm{ha}^{-1} \mathrm{yr}^{-1}$ for the L-EN system and $8826 \mathrm{MJ} \mathrm{ha}^{-1} \mathrm{yr}^{-1}$ for the PHEP system (Fig. 1). Chemicals, including $\mathrm{N}$ fertilizers, the largest component, accounted for $1271 \mathrm{MJ} \mathrm{ha}^{-1} \mathrm{yr}^{-1}$ (43\% of total indirect energy consumption) in the L-EN system and $4345 \mathrm{MJ} \mathrm{ha}^{-1} \mathrm{yr}^{-1}(95 \%$ of total indirect energy consumption) in the PHEP system. The use of machinery for tillage, fertilization, harvesting and sowing and crop protection was the only component of direct energy consumption that was nearly halved in the L-EN system (2976 $\mathrm{MJ} \mathrm{ha}^{-1} \mathrm{yr}^{-1}$ and $4228 \mathrm{MJ} \mathrm{ha}^{-1} \mathrm{yr}^{-1}$ for the L-EN and the PHEP systems, respectively). The difference between these two systems can be accounted for by the absence of tillage and the use of less $\mathrm{N}$ fertilizer in the L-EN cropping system.

When expressed in $\mathrm{MJ} \mathrm{ha}^{-1}$, the total fossil energy in the L-EN system is $49 \%$ lower than that in the PHEP system (Table 4). However, if expressed in $\mathrm{MJ} \mathrm{t}^{-1}$, the energy performance of the L-EN system is lower (i.e., difference between the PHEP and the L-EN systems of only $24 \%$ in term of total fossil energy per ton of produce), because the target yield is about 20\% lower. A similar reduction in energy use (about 29\%) was observed for the calculation in $\mathrm{kJ} \mathrm{kcal}^{-1}$.

The GHG constraint in the L-GHG cropping system. $\mathrm{C}$ sequestration was assessed for the optimized prototypes of the PHEP and the L-GHG systems, for the mean SOM content in the Ile-de-France region (1.6\%). Both the Roth $\mathrm{C}$ model and the SIMEOS ${ }^{\circledR}$ tool predicted that $\mathrm{C}$ would be sequestered throughout the study period, from the start, in both cropping systems. The highest values were obtained with the L-GHG system over a 50 -year period, for both assessment tools (Table 5). For both systems, total $\mathrm{C}$ sequestration was higher during the first 25-year period than during the second 25-year period. When expressed in $\mathrm{t} \mathrm{CO}_{2}$-eq ha ${ }^{-1}, \mathrm{C}$ sequestration values were systematically higher with the Roth $\mathrm{C}$ model than with the SIMEOS $^{\circledR}$ tool. Nevertheless, after 25 and 50 years, the differences between the L-GHG and the PHEP systems calculated with the Roth $\mathrm{C}$ model and the SIMEOS ${ }^{\circledR}$ tool were similar if the results were expressed in relative values. Direct and indirect GHG emissions were calculated with the GES'TIM database, over one rotation period, for the L-GHG and the PHEP cropping systems (Fig. 2). Mean total $\mathrm{GHG}$ emissions were $1104 \mathrm{~kg} \mathrm{CO}_{2}$-eq ha ${ }^{-1} \mathrm{yr}^{-1}$ and $1273 \mathrm{~kg} \mathrm{CO}_{2}$-eq ha ${ }^{-1} \mathrm{yr}^{-1}$ for the L-GHG and the PHEP cropping systems, respectively. Direct and indirect GHG emissions accounted for similar proportions of total emissions: 48 and 52\% for direct GHG emissions for the L-GHG and PHEP systems, respectively (Table 6). Chemical fertilizers caused both direct and indirect GHG emissions. They represented 76 and $73 \%$ of total GHG emissions for the L-GHG and the PHEP systems, respectively. Soil cultivation, accounting for 19 and $23 \%$ of total GHG emissions for the L-GHG and the PHEP systems, respectively, was the second most important component of these emissions. When results were expressed per ha, total GHG emissions were 13\% lower in the L-GHG system than in the PHEP system. When expressed per ton of produce, the larger decrease $(22 \%)$ may be accounted for by the higher yields, calculated at rotation scale, of the L-GHG system than of the PHEP system.

In terms of the overall balance of GHG emissions (Tables 7 and 8), GHG values were negative for the L-GHG system, except for the 50-year period with the SIMEOS $^{\mathbb{R}}$ tool. All GHG balance values were lower for the L-GHG system than for the PHEP system. The difference in GHG balance between the two systems increased over time, and was greater with the Roth $\mathrm{C}$ model, which gave decreases in GHG emission of $51 \%$ for the 25 -year period and $76 \%$ for the 50 -year period.

\section{Assessment of environmental targets}

The results of assessments of environmental targets with the INDIGO $^{\circledR}$ tool are shown in Figure 3. For all optimized cropping systems, all 11 indicators had values 
Table 4. Comparisons of total fossil energy consumption, expressed in $\mathrm{MJ} \mathrm{ha}^{-1}, \mathrm{MJ} \mathrm{t}^{-1}$ and kJ kcal ${ }^{-1}$ (INDIGO ${ }^{\circledR}$ tool, v.1.9), between cropping systems. Cropping systems: PHEP (productive high environmental performance), L-EN (low-energy use) and IdF (current system in Ile-de-France region).

\begin{tabular}{lccc}
\hline & $\begin{array}{c}\text { Total fossil energy consumption } \\
\left(\mathbf{M J} \mathbf{~ h a}^{-\mathbf{1}} \mathbf{)}(\mathbf{\%})\right.\end{array}$ & $\begin{array}{c}\text { Total fossil energy consumption } \\
\left(\mathbf{M J} \mathbf{t}^{-\mathbf{1}}\right) \mathbf{( \% )}\end{array}$ & $\begin{array}{c}\text { Total fossil energy consumption } \\
\left(\mathbf{k J} \mathbf{~ k c a l} \mathbf{~}^{-\mathbf{1}}\right) \mathbf{( \% )}\end{array}$ \\
\hline L-EN-PHEP PHEP & -49 & -24 & -29 \\
PHEP-IdF IdF & -31 & -21 & -30 \\
L-EN-IdF IdF & -65 & -40 & -50 \\
\hline
\end{tabular}

Table 5. C sequestration ( $\mathrm{t} \mathrm{CO}_{2}$-eq ha ${ }^{-1}$ ) simulated over 25 -year and 50-year periods for the different cropping systems with the ROTH C model (V.26-3) and the SIMEOS ${ }^{\circledR}$ tool (2010), for mean SOM content in the Ile-de-France region $(1.6 \%$. SOM $=123.3 \mathrm{t}$ $\mathrm{CO}_{2}$-eq ha ${ }^{-1}$ ). Cropping systems: PHEP (productive high environmental performance), L-GHG (low greenhouse gas emissions) and $\mathrm{IdF}$ (current system in Ile-de-France region).

\begin{tabular}{|c|c|c|c|}
\hline $\mathrm{C}$ sequestration $\left(\mathrm{t} \mathrm{CO}_{2}-\mathrm{eq} \mathrm{ha}^{-1}\right)$ & & $\begin{array}{l}\text { Assessment period } \\
\text { (25 years) }\end{array}$ & $\begin{array}{l}\text { Assessment period } \\
\text { (50 years) }\end{array}$ \\
\hline Cropping systems & Tool or model & & \\
\hline PHEP & SIMEOS $^{\circledR}$ tool & 15.1 & 19.7 \\
\hline PHEP & ROTH C model & 85.2 & 116.0 \\
\hline L-GHG & SIMEOS $^{\circledR}$ tool & 32.0 & 40.5 \\
\hline L-GHG & ROTH C model & 102.9 & 147.8 \\
\hline $\mathrm{IdF}$ & SIMEOS $^{\circledR}$ tool & 17.4 & 22.1 \\
\hline $\mathrm{IdF}$ & ROTH C model & 87.1 & 129.2 \\
\hline (L-GHG-PHEP) PHEP SOC & SIMEOS $^{\circledR}$ tool & $12 \%$ & $15 \%$ \\
\hline (L-GHG-PHEP) PHEP SOC & ROTH C model & $9 \%$ & $13 \%$ \\
\hline
\end{tabular}

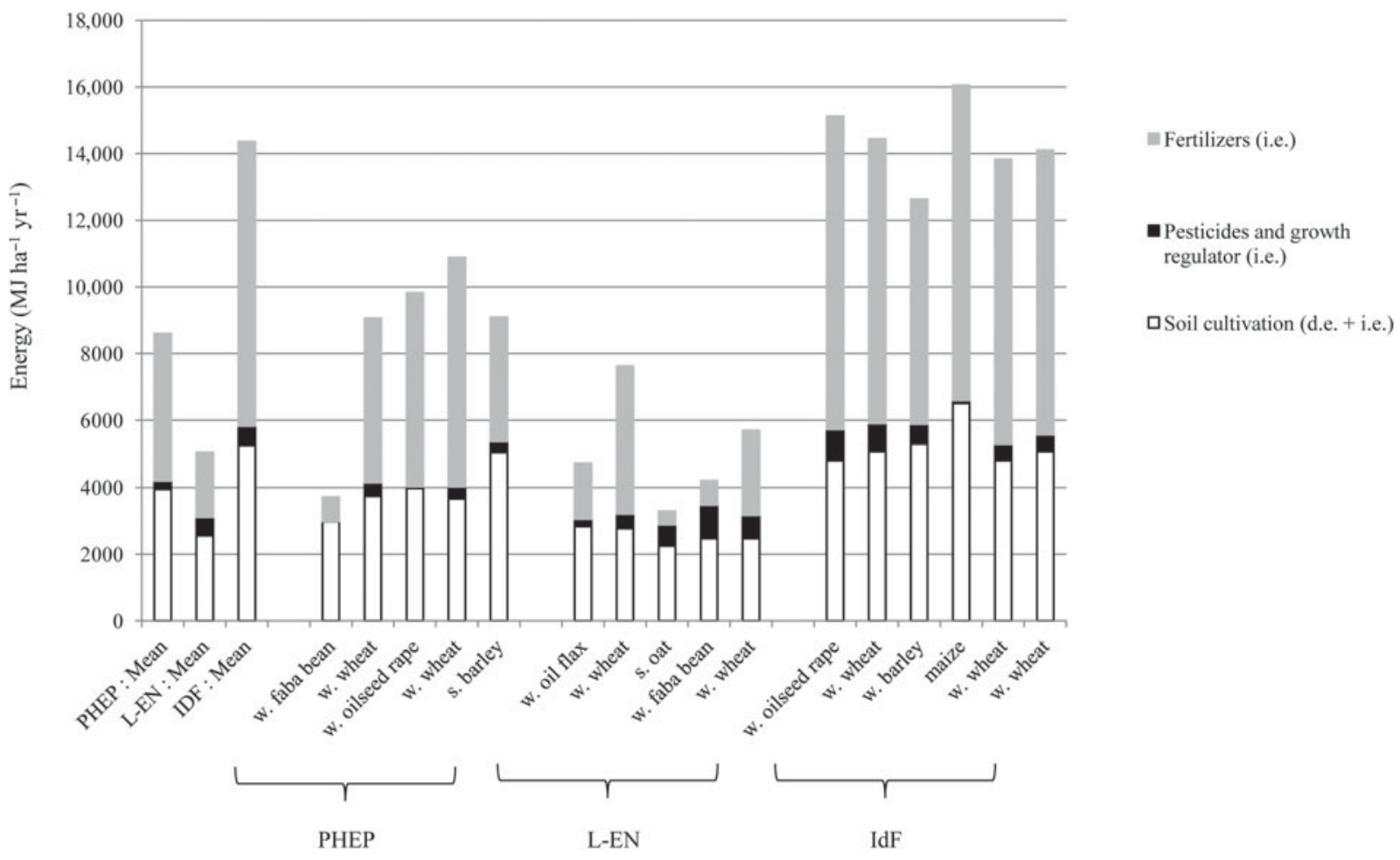

Figure 1. Cropping system prototypes assessment with GES'TIM database: mean total fossil energy consumption (expressed in $\mathrm{MJ} \mathrm{ha}^{-1} \mathrm{yr}^{-1}$ ) calculated over one rotation period for the different cropping systems, and total fossil energy consumption for each crop of the various cropping systems (i.e., indirect energy; d.e., direct energy; w, winter; s, spring). Cropping systems: PHEP (productive high environmental performance), L-EN (low-energy use) and IdF (current system in Ile-de-France region). 


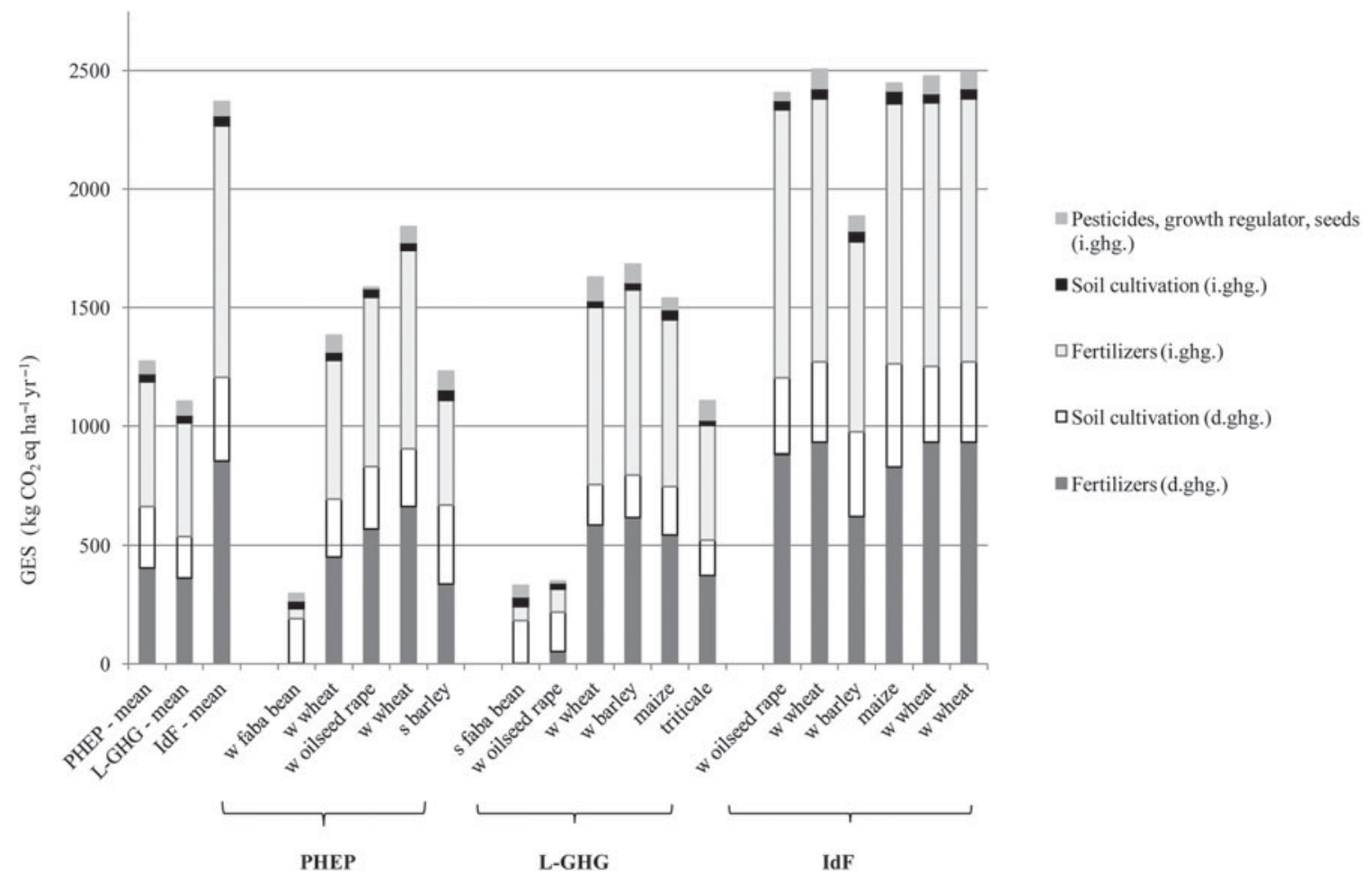

Figure 2. Cropping system prototypes assessment with GES'TIM database: Mean total greenhouse gas emissions (expressed in kg $\mathrm{CO}_{2}$-eq ha ${ }^{-1} \mathrm{yr}^{-1}$ ) calculated over one rotation period for the different cropping systems, and total greenhouse gas emissions for each crop of the various cropping systems (i.ghg, indirect greenhouse gas; d.ghg, direct greenhouse gas; w, winter; s, spring). Cropping systems: PHEP (productive high environmental performance), L-GHG (low greenhouse gas emissions) and IdF (current system in Ile-de-France region).

Table 6. Comparison of total simulated GHG emissions, expressed in $\mathrm{t} \mathrm{CO}_{2}-\mathrm{eqha}^{-1}$ and $\mathrm{t} \mathrm{CO}_{2}-\mathrm{eqt}^{-1}$, between cropping systems. Cropping systems: PHEP (productive high environmental performance), L-GHG (low greenhouse gas emissions) and IdF (current system in Ile-de-France region).

\begin{tabular}{|c|c|c|}
\hline & $\begin{array}{c}\text { Total greenhouse } \\
\text { gas emissions } \\
\left(\mathrm{t} \mathrm{CO} \mathrm{C}_{2}-\mathrm{eq} \mathrm{ha}^{-1}\right) \\
(\%)\end{array}$ & $\begin{array}{c}\text { Total greenhouse } \\
\text { gas emissions } \\
\left(\mathrm{t} \mathrm{CO}-\mathrm{eq}^{-1}\right) \\
(\%)\end{array}$ \\
\hline L-GHG-PHEP PHEP & -13 & -22 \\
\hline PHEP_IdF IdF & -46 & -32 \\
\hline L-GHG-IdF IdF & -53 & -47 \\
\hline
\end{tabular}

of at least 7 (i.e., environmental criteria were satisfied), except for the organic matter indicator (OMI) for the No-Pest cropping system $(\mathrm{OMI}=5.7)$. The large number of species (more than three in each rotation) and the small quantities of pesticides sprayed on crops ( $0-2$ pesticides used per crop), the systematic restitution of residues and the optimization of tillage and fertilization management (i.e., the small number of plowing operations, optimizing $\mathrm{P}$ and $\mathrm{N}$ fertilization in terms of both the amounts applied and the timing of applications), resulted in high values for the indicators for crop diversity, pesticide use, SOM, phosphorus, nitrogen and fossil fuel, respectively.
The low value of the OMI for the No-Pest cropping system (5.7) could be accounted for by both the large number of plowing operations (alternate years), encouraging mineralization and the lower yields, resulting in smaller amounts of $\mathrm{C}$ residues.

\section{Discussion}

\section{Design and assessment of innovative cropping systems}

The main challenge of this study was to design innovative cropping systems. Our approach is original in the multiplicity of purposes assigned to these systems (i.e., association of one major constraint with environmental and yield targets). In most previous studies, these issues have been analyzed separately. For example, Zentner et al. ${ }^{60}$ and Gelfand et al. ${ }^{40}$ studied energy efficiency, whereas Nemecek et al. ${ }^{28}$ used life cycle assessment methods to evaluate environmental criteria, Nowacki ${ }^{61}$ studied profitability, and Chikowo et al. ${ }^{35}$ studied new cropping systems with a lower reliance on pesticides. However, several other studies are currently investigating system sustainability including assessments of several different criteria $^{62}$, or numerous environmental parameters ${ }^{22}$. In our project, we combined one major constraint with environmental and yield targets, reflecting the multifunctionality of 
Table 7. Greenhouse gas balances ( $\mathrm{t} \mathrm{CO}_{2}$-eqha $\left.{ }^{-1}\right)$, for different cropping systems, determined with the SIMEOS ${ }^{\circledR}$ tool (2010) and the ROTH C model (V.26-3), for a current soil in the Ile-de-France region (SOM $=1.6 \%$ ) and the $\mathrm{GES}^{\prime} \mathrm{TIM}^{49}$ database, for 25-year and 50-year periods. The GHG balance is positive when the amount of $\mathrm{C}$ emitted in greenhouse gases exceeds that sequestered. Cropping systems: PHEP (productive high environmental performance), L-GHG (low-greenhouse gas emissions) and IdF (current system in Ile-de-France region).

\begin{tabular}{|c|c|c|c|}
\hline $\begin{array}{l}\text { Greenhouse } \\
\text { gas balances } \\
\left(\mathrm{t} \mathrm{CO}_{2} \text { eq ha }^{-1}\right) \text {, }\end{array}$ & & $\begin{array}{l}\text { Assessment } \\
\text { period } \\
\text { (25 years) }\end{array}$ & $\begin{array}{c}\text { Assessment } \\
\text { period } \\
\text { (50 years) }\end{array}$ \\
\hline Cropping system & Tool or model & & \\
\hline PHEP & SIMEOS $^{\circledR}$ tool & 16.7 & 44.0 \\
\hline PHEP & ROTH C model & -53.4 & -52.3 \\
\hline L-GHG & SIMEOS $^{\circledR}$ tool & -4.4 & 14.4 \\
\hline L-GHG & ROTH C model & -75.3 & -92.6 \\
\hline $\mathrm{IdF}$ & SIMEOS $^{\circledR}$ tool & 41.9 & 96.4 \\
\hline $\mathrm{IdF}$ & ROTH C model & -39.7 & -10.8 \\
\hline L-GHG-PHEP & SIMEOS $^{\circledR}$ tool & -21.1 & -29.3 \\
\hline L-GHG-PHEP & ROTH C model & -21.9 & -40.3 \\
\hline
\end{tabular}

agriculture. Furthermore, there was a clear, particular hierarchy throughout the design process. In most published experiments, environmental consequences are assessed only during the assessment of technical innovations in the trials, or environmental goals exist but are not quantified at the start of the study. In our work, satisfying the major constraints and the precise environmental targets were major aims, which became the conditions determining yield, with target yields set as high as possible under the conditions concerned. In addition, the clear definition of the constraint (i.e., reducing energy consumption or GHG emissions by $50 \%$ ) and the environmental targets (i.e., having a value of at least 7 for all INDIGO environmental indicators) was also original. The quantitative levels of the constraints did not correspond to any regulations (i.e., these constraints reflected a major break with the regulations). However, these innovative cropping systems were considered as research tools which enabled identification of the most relevant agronomic practice combinations which could be used in more restrictive legislative contexts. The level quantifications of the constraints and environmental targets were very useful during the design process which required calculations.

Before the assessment of the prototypes in a long-term field trial, candidate systems were assessed and improved in an iterative process until the constraints were satisfied and environmental performance with respect to targets was optimized. This theoretical process of improvement has rarely been reported in previous studies. Cropping systems are usually assessed or compared in systems defined on the basis of the main standardized characteristics, essentially relating to one major aspect: e.g., organic versus conventional systems $\mathrm{s}^{24,63,64}$, no-tillage versus
Table 8. Greenhouse gas balance ratio of the various cropping systems, expressed in $\mathrm{t} \mathrm{CO}_{2}$-eq ha ${ }^{-1}$, simulated with the ROTH C (V.26-3) model over two different periods (25 and 50 years). Cropping systems: PHEP (productive high environmental performance), L-GHG (low greenhouse gas emissions) and $\mathrm{IdF}$ (current system in Ile-de-France region).

\begin{tabular}{lcc}
\hline & $\begin{array}{c}\text { GHG balance: } \\
\text { 25 years }\end{array}$ & $\begin{array}{c}\text { GHG balance: } \\
\text { 50 years }\end{array}$ \\
\hline L-GHG/PHEP & 1.51 & 1.76 \\
PHEP/IdF & 1.39 & 4.95 \\
L-GHG/IdF & 2.10 & 8.72 \\
\hline
\end{tabular}

conventional tillage ${ }^{64,65}$ or integrated versus conventional systems ${ }^{61,66}$. Quantitative data for environmental criteria $^{26}$, yield ${ }^{67}$ or economic performance ${ }^{68,69}$ were therefore recorded in experiments. The results of these comparisons can be used to compare the impact of different systems, but not to identify all solutions for their improvement. Even though inductive reasoning can bring about some conclusions with regard to general principles, another round of conception and evaluation is required, to strengthen cropping systems. Our prototyping approach is totally different. Innovative systems were assessed by modeling until they satisfied specific constraints and were optimized in terms of specific environmental targets. A field trial was then set up to determine whether each of the selected prototypes could satisfy its multiple constraints and targets. In this case, the various environmental targets were included in the agricultural strategies from the start of the design process, facilitating identification of the weaknesses of the system and making it possible to propose solutions for improvement before undertaking field trials. After the assessment of these innovative cropping systems in a field trial, their costs and economic performances will be calculated in different economic scenarios, to determine the likelihood of their being adopted by farmers.

Our approach required a large panel of experts (scientists, farmers and extension service staff) to design and to support prototypes throughout the design process (i.e., from the first to the last candidates). This was necessary because (1) the best crop management system may not correspond simply to the sum of individual agricultural practices, but may instead involve a set of agronomic strategies and their interactions; and (2) a breadth of agro-ecological knowledge is required to identify sets of agricultural rules likely to be responsive to such strict constraints and environmental targets. Moreover, this approach provided a more realistic view of cropping systems, making the adoption of the proposed innovations more likely ${ }^{70}$. However, the field trial assessment step is still absolutely necessary because some innovative agronomic practices, not currently used in cropping systems, have never been evaluated by experts. 


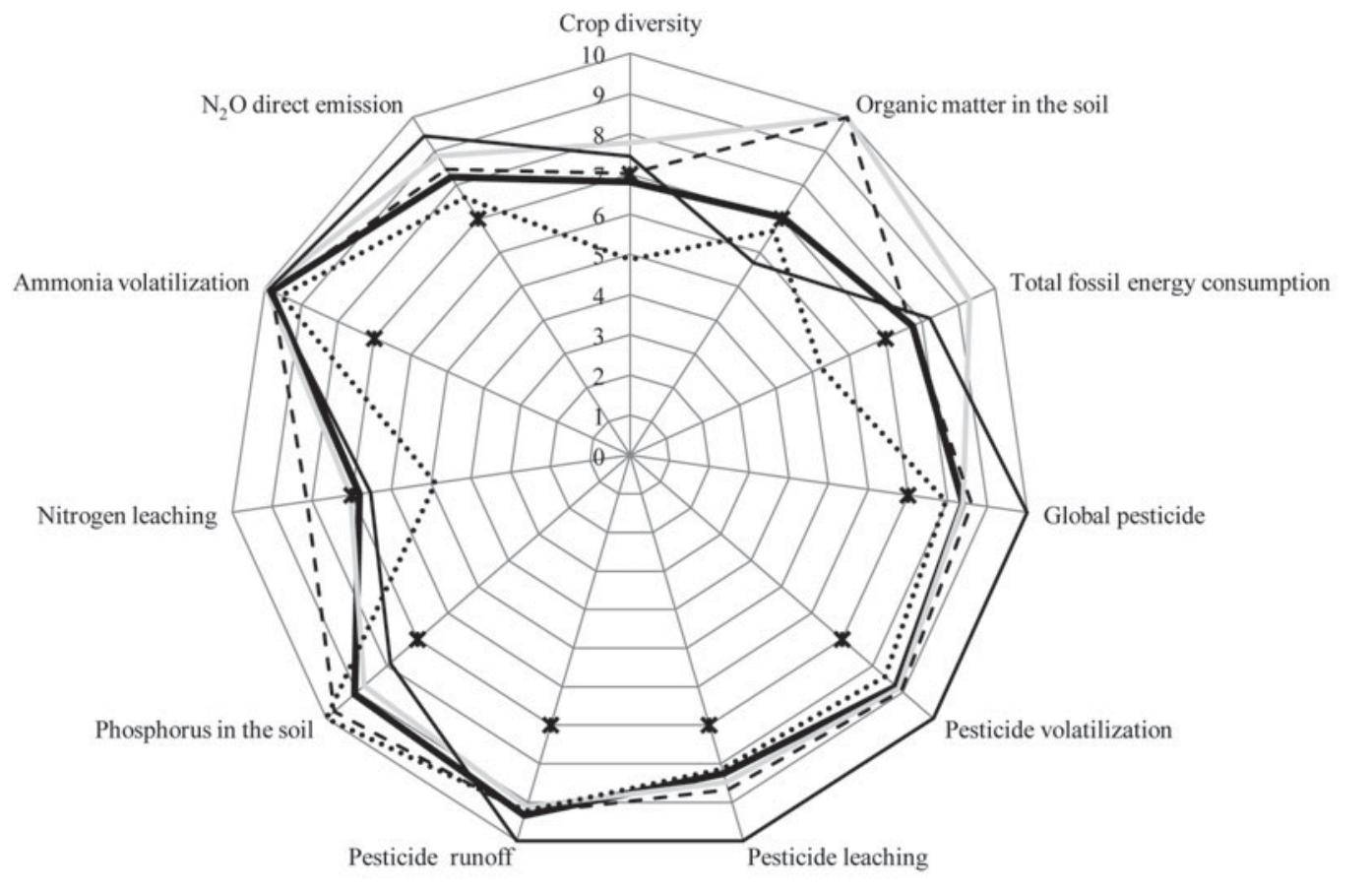

$\longrightarrow$ PHEP $\longrightarrow$ L-EN $\quad---$ L-GHG $\quad$ No Pest $\quad \cdots .$. IdF $\quad$ × Min values to satisfy environmental targets

Figure 3. Environmental criteria assessment of the different cropping system prototypes with the INDIGO ${ }^{\circledR}$ tool (v.1.9). Cropping systems: PHEP (productive high environmental performance), L-GHG (low greenhouse gas emissions), L-EN (low-energy use), No-Pest (No pesticides) and IdF (current system in Ile-de-France region). Minimum values to satisfy environmental targets.

During the design process, about 15 experts attended individual sessions or group meetings, to provide knowledge unavailable from published work. The definition of crop rotations and agronomic practices took about 6 months, and a further 18 months were required for the writing of the decision rules. Published studies involving design processes have differed considerably in the number of experts involved and the time spent by individual experts, depending on the availability of the experts and the difficulties encountered in achieving the goals assigned to systems ${ }^{62,71}$.

\section{Achievement of multiple constraints and targets}

For all innovative systems, the constraints were satisfied with no consequences for other environmental components, except for the OMI of the No-Pest system. In this case, regular tillage combined with the restitution of only small amounts of organic matter had an adverse effect on soil environmental characteristics (indicator value for SOM of 5.7, according to the INDIGO ${ }^{\circledR}$ tool). Within this system, it did not appear to be possible to satisfy both the constraint and this environmental target with the available non-chemical techniques for pest control. Moreover, this was only possible with the available techniques by reducing yield targets with respect to those of current regional systems $\left(\right.$ Agreste $\left.^{57}\right)$.
Nevertheless, progress in integrated pest management is being made, and new techniques may make it possible to improve environmental and yield performances. In the design of the L-EN system, we managed various agricultural processes, decreasing both direct energy consumption (e.g., due to tillage) and indirect energy consumption (due to the use of mineral fertilizers). We halved fossil energy consumption by greatly decreasing $\mathrm{N}$ fertilizer inputs, which was associated with a $20 \%$ yield loss. However, the energy performance of the L-EN system was expressed relative to that of the PHEP system, which also had a relatively low level of fossil fuel consumption with respect to current practices in Ile-deFrance. The total energy consumption of the L-EN system was about $35 \%$ that of the current system in Ile-deFrance (Agreste ${ }^{57}$ ), when energy was expressed in MJ $\mathrm{ha}^{-1}$ (Table 4). For both the L-GHG and the PHEP systems, decreases in pesticide were taken into account by considering the maximum achievable yields to be similar to those of current low-input systems in Ile-deFrance (Agreste ${ }^{57}$ ), and much lower than those of conventional systems in the region $\left(\right.$ Agreste $\left.^{57}\right)$. Achievable yields for the L-GHG and the PHEP systems were considered to be 13 and $21 \%$ lower, respectively, than those of the current system in Ile-de-France. However, considering all the innovative systems together, it would appear to be possible to satisfy such ambitious constraints 
and environmental targets at the expense of only relatively small yield losses.

Available knowledge and current techniques suggested that it would not be possible to overcome all constraints in a single cropping system, because the agronomic practices used in one innovative system were incompatible with the constraints imposed on others. Plowing, one of the most effective practices against weeds used in the No-Pest system, is incompatible with large decrease in fossil energy consumption and the increase in $\mathrm{C}$ sequestration achieved with the L-EN and L-GHG systems, respectively. The large decrease in $\mathrm{N}$ fertilizer levels of the L-EN system is not compatible with the achievable yields defined for the PHEP and the L-GHG systems. Winter wheat sowing was delayed to avoid pest pressure in the No-Pest system, whereas it was brought forward in the direct drilling conditions of the L-EN and the L-GHG systems. This pattern was already evident during the design of the L-GHG system (i.e., GHG emission processes were managed in hierarchical order). Consequently, the development of a system without pesticides, with ambitious constraints in terms of GHG emissions and fossil fuel use, and with other environmental and yield targets, will require further progress in agronomic knowledge. For example, a better understanding of the interactions between cash and cover crops in terms of cooperative and competitive effects might allow the introduction of a living cover crop during cash crop growth in the L-GHG system ${ }^{72}$. The field trial assessment again proves essential to gain a better understanding of these interactions.

\section{Improving the design process}

In the design of the L-GHG system, we had to rank the secondary objectives (C sequestration had to be enhanced first, and then $\mathrm{N}_{2} \mathrm{O}$ emissions had to be reduced) to satisfy the GHG constraint. In this case, several practices had effects on both processes involved: no-tillage increased $\mathrm{C}$ sequestration in the soil but increased $\mathrm{N}_{2} \mathrm{O}$ emissions; ample $\mathrm{N}$ fertilizer applications were required to obtain high yields and, thus, abundant $\mathrm{C}$ residues, but this also generated more $\mathrm{N}_{2} \mathrm{O}$ emissions. We decided to promote $\mathrm{C}$ sequestration, because $\mathrm{N}_{2} \mathrm{O}$ emission assessments were highly uncertain due to the lack of published data about $\mathrm{N}_{2} \mathrm{O}$ emissions, for field bean residues for example (IPPC ${ }^{51}$ ), and the variability of results due to differences in soil and climatic conditions ${ }^{44}$. Nevertheless, knowledge about the effects of cropping systems on $\mathrm{N}_{2} \mathrm{O}$ emissions is increasing, and it should be possible to improve the adjustment of cropping systems in the future.

The cropping systems assessment required tools and models adapted to the set of objectives and convenient to use during the iterative optimization process. Some approximations were used, due to the lack of data. In the L-GHG system, the coefficient defined by the
Intergovernmental Panel on Climate Change (Tier 1) was used to calculate $\mathrm{N}_{2} \mathrm{O}$ release from the amount of $\mathrm{N}$ applied, rather than using different values for different soil and climatic conditions ${ }^{44}$. There were also uncertainties in the assessment of $\mathrm{C}$ sequestration. The two simulations provided similar ranks for the PHEP and the L-GHG systems, but the SIMEOS ${ }^{\circledR}$ tool and the Roth C model gave different quantitative results. One difference between these tools relates to tillage. In the SIMEOS ${ }^{\circledR}$ tool, mineralization mechanisms in the tilled layer are modified by tillage ${ }^{48}$. In the Roth $\mathrm{C}$ model, tillage is taken into account only indirectly, through the $\mathrm{C}$ inputs to the soil from crop biomass, which are affected by tillage practices $^{55}$. Further uncertainties arise from the lack of root biomass data. Furthermore, these tools partially take into account changes in SOM content, which greatly influence $\mathrm{N}$ transformation mechanisms in the soil. Anyway, the difference in the values generated by these models suggested that neither may accurately predict actual performances of these contrasting cropping systems. If cropping systems assessment is to be considered relevant, it must make use of tools that are regularly updated, including: (1) 'new' machinery, such as harrows, hoes or directsowing drills with adjustable parameters in terms of energy consumption and GHG emissions; and (2) new more forms of pesticides or fertilizers. It may also be useful to improve systems assessments with crop models, but many parameters are unavailable for marginal crops (such as hemp or flax), for crop mixtures (e.g., cereal and legume combinations), or species mixtures used as catch crops (e.g., the association of spring oats, mustard and clover).

Several economic and social aspects were not taken into account during this design process, which focused on the cropping system rather than the farm scale. Nevertheless, we excluded some crops that are not grown by farmers in Ile-de-France due to the lack of a market (i.e., with low economic performances), but we included others for which the market is poorly developed in this area (e.g., lucerne and hemp). We did not take the organization of farm work into account either, although the identification and quantification of pest pressures in the field, to decrease pesticide use, is known to be time-consuming. From a technical point of view, we assumed that all farms owned the specific machinery used in the innovative systems, such as directsowing drills or mechanical weeding tools. For all these reasons, further investigations of the most relevant innovative cropping systems identified in a field trial assessment are needed, to forecast their possible application in an area.

\section{Toward field assessment of the innovative cropping system prototypes}

The innovative systems prototypes designed here were based on different hypotheses about soil and climate 
effects, because the true impact on crops and soil are unknown. For example, we assumed that agricultural practices and climatic conditions would not affect crop emergence. In our conditions, crops are not affected by direct drilling because this technique is widely used in France (http://agriculture-de-conservation.com/). However, conservation tillage and mulch tillage practices remain largely empiric ${ }^{73}$, and additional knowledge is required for the optimization of these techniques, to make it possible to achieve good results in terms of sowing management and target yields. We also assumed that rainfall would provide enough water throughout the year in northern France to allow catch crop and main crop emergence, but this may no longer be the case if the climate changes radically. We assumed that new equilibria would appear with certain practices, allowing inputs to be reduced. In the L-GHG system, the practice of leaving crop residues on the soil should decrease weed emergence, making it possible to decrease the amount of herbicide used, and the absence of plowing should lead to the maintenance or increase in size of ground beetle populations, making molluscicide use unnecessary. The achievable yield was determined on the basis of several assumptions. In the L-GHG system, we promoted $\mathrm{C}$ sequestration, which is highly dependent on cereal yields and difficult to estimate in the case of no-tillage systems, because the presence of excessive amounts of crop residues may decrease emergence. The chemical properties of the soil associated with different tillage practices are also poorly characterized ${ }^{73}$. In this system, the effects on water availability of sowing cover crops every year also should be analyzed. In the L-EN system, the mixture of winter wheat and white clover might also decrease cereal yields. In the No-Pest system, yields were defined by approximation to organic systems, in which no mineral fertilizers are permitted. In this system, late winter cereal sowing might lead to higher levels of damping-off and plant death during winter, decreasing yields to a greater extent than anticipated. These are just a few of the uncertainties remaining about the real performance of the systems we have devised. For these reasons, the field assessment of these system prototypes, which is currently being carried out (the experiment started in 2008), is absolutely necessary.

Finally, it should be stressed that approaches of this type could be used in many agronomic situations, with a diversity of challenges, provided that sufficient knowledge is available for the development of innovative strategies. In our opinion, this approach meets the need expressed by Foley et al. ${ }^{14}$ to 'search for practical solutions' for a cultivated planet.

Acknowledgements. We thank the experts who took part in the design process, Marie-Hélène Jeuffroy, Jane Jonhson, Laurence Guichard, Marie Gosme and David Makowski for their useful comments on a previous version of the paper, Suzette TanisPlant for linguistic help and Alain Bone for assistance with bibliographic research.

\section{References}

1 IFEN, 2007. Les pesticides dans les eaux - données 2005. Les dossiers $-n^{\circ} 9$. Available at Web site http://www.ifen.fr/ publications/le-catalogue-despublications/ les-dossiers/2007/ les-pesticides-dans-les-eaux-donnees-2005.html (accessed August 22, 2014).

2 Schrack, D., Coquil, X., Ortar, A., and Benoît, M. 2009. Rémanence des pesticides dans les eaux issues de parcelles agricoles récemment converties à l'Agriculture Biologique. Innovations Agronomiques 4:259-268.

3 Höök, M., Sivertsson, A., and Aleklett, K. 2010. Validity of the fossil fuel production outlooks in the IPCC Emission Scenarios. Natural Resources Research 19(2):63-81.

4 Jakobsson, K., Söderbergh, B., Höök, M., and Aleklett, K. 2009. How reasonable are oil production scenarios from public agencies? Energy Policy 37:4809-4818.

5 Shafiee, S. and Topal, E. 2009. When will fossil fuel reserves be diminished? Energy Policy 37(1):181-189.

6 Mohr, S.H. and Evans, G.M. 2010. Long term prediction of unconventional oil production. Energy Policy 38(1): 265-276.

7 Smith, P., Martino, D., Cai, Z., Gwary, D., Janzen, H., Kumar, P., McCarl, B., Ogle, S., O'Mara, F., Rice, C., Scholes, B., and Sirotenko, O. 2007. Agriculture. In B. Metz, O.R. Davidson, P.R. Bosch, R. Dave, and L.A. Meyer (eds). Climate Change 2007: Mitigation. Contribution of Working Group III to the Fourth Assessment Report of the Intergovernmental Panel on Climate Change. Cambridge University Press, Cambridge, UK and New York, NY, USA.

8 Galloway, J.N., Townsend, A.R., Erisman, J.W., Bekunda, M., Cai, Z.C., Freney, J.R., Martinelli, L.A., Seitzinger, S.P., and Sutton, M.A. 2008. Transformation of the nitrogen cycle: recent trends, questions, and potential solutions. Science 16;320(5878):889-892. doi: 10.1126/science. 1136674.

9 Arrouays, D., Balesdent, J., Germon, J.C., Jayet, P.A., Soussana, J.F., and Stengel, P., 2002. Expertise scientifique collective 'Contribution à la lutte contre l'effet de serre' Stocker du carbone dans les sols agricoles de France? Collective Scientific Expert Report. INRA edition. p. 332.

10 Spiertz, J.H.J. 2010. Nitrogen, sustainable agriculture and food security. A Review Agronomic Sustainable Development 30(2010):43-55.

11 Matson, P.A., Parton, W.J., Power, A.G., and Swift, M.J. 1997. Agriculture intensification and ecosystems properties. Science 277:504-509.

12 UNEP 2007. Available at Web site http://www.unep.org/ PDF/AnnualReport/2007/AnnualReport2007_en_web.pdf (accessed August 22, 2014).

13 Bouman, B.A.M., Humphreys, E., Tuong, T.P., and Barker, R. 2007. Rice and water. Advances in Agronomy 92:187-237.

14 Foley, J.A., Ramankutty, N., Brauman, K.A., Cassidy, E.S., Gerber, J.S., Johnston, M., Mueller, N.D., O'Connell, C., Ray, D.K., West, P.C., Balzer, C., Bennett, L.M., Carpenter, S.R., Hill, J., Monfreda, C., Polasky, S., Rockström, J., Sheehan, J., and Siebert, S., 2011. Solutions for a cultivated planet. Nature 478:337-342.

15 Aubertot, J.N., Barbier, J.M., Carpentier, A., Gril, J.J., Guichard, L., Lucas, P., Savary, S., Savini, I., and Voltz, M. 
2005. Pesticides, agriculture and the environment: reducing the use of pesticides and limiting their environmental impact. Collective Scientific Expert Report. INRA - CEMAGREF. INRA edition. p. 63.

16 Köpke, U. and Nemecek, T. 2010. Ecological services of faba bean. Field Crops Research 115(2010):217-233.

17 Beheydt, D., Boeckx, P., Ahmed, H.P., and Van Cleemput, O. 2008. $\mathrm{N}_{2} \mathrm{O}$ emissions from conventional and minimum-tilled soils. Biology and Fertility of Soils 44:863-873.

18 Van Kessel, C., Ventera, R., Six, J., Arlene, M., Borde, A., Linquist, B., and Van Groenigen, K. 2013. Climate, duration, and $\mathrm{N}$ placement determine $\mathrm{N}_{2} \mathrm{O}$ emissions in reduced tillage systems: a meta-analysis. Global Change Biology 19(1):33-44.

$19 \mathrm{Fu}$, WeiJun, Tunney, H., and Zhang, Chao Sheng. 2010. Spatial variation of soil test phosphorus in a long-term grazed, experimental grassland field. Journal of Plant Nutrition and Soil Science 173(3):323-331.

20 Heinze, S., Raupp, J., and Joergensen, R.G. (2010). Effects of fertilizer and spatial heterogeneity in soil $\mathrm{pH}$ on microbial, biomass indices in a long-term field trial of organic agriculture. Plant and Soil 328(1/2): 203-215.

21 Chirinda, N., Olesen, J.E., Porter, J.R., and Schjønning, P. 2010. Soil properties, crop production and greenhouse gas emissions from organic and inorganic fertilizer-based arable cropping systems. Agriculture, Ecosystems and Environment 139(4):584-594.

22 Tuomisto, H.L., Hodge, I.D., Riordan, P., and Macdonald, D.W. 2012. Comparing energy balances, greenhouse gas balances and biodiversity impacts of contrasting farming systems with alternative land uses. Agricultural Systems 108:42-49.

23 Shadbolt, N., Kelly, T., Horne, D., Harrington, K., Kemp, P., Palmer, A., and Thatcher, A. 2009. Comparisons between organic and conventional pastoral dairy farming, systems: cost of production and profitability. Journal of Farm Management 13(10):671-685.

24 De Ponti, T., Rijk, B., and Van Ittersum, M. 2012. The crop yield gap between organic and conventional agriculture. Agricultural Systems 108:1-9.

25 Simonsen, J., Posner, J., Rosemeyer, M., and Baldock, J. 2010. Endogeic and anecic earthworm abundance in six Midwestern cropping systems. Applied Soil Ecology 44:147-155.

26 Riley, H., Pommeresche, R., Eltun, R., Hansen, S., and Korsaeth, A. 2008. Soil structure, organic matter and earthworm activity in a comparison, of cropping systems with contrasting tillage, rotations, fertilizer, levels and manure use. Agriculture, Ecosystems Environment 124(3/4):275-284.

27 Snapp, S.S., Gentry, L.W., and Harwood, R. 2010. Management intensity-not biodiversity-the driver of ecosystem services in a long-term row crop experiment. Agriculture, Ecosystems and Environment 138:242-248.

28 Nemecek, T., Dubois, D., Huguenin-Elie, O., and Gaillard, G. 2011. Life cycle assessment of Swiss farming systems: I. Integrated and organic farming. Agricultural Systems 104(2011):217-232.

29 Vereijken, P. 1997. A methodological way of prototyping integrated and ecological arable farming systems (I/EAFS) in interaction with pilot farms. European Journal of Agronomy $7: 235-250$.
30 Dogliotti, S., Van Ittersum, M.K., and Rossing, W.A.H. 2005. A method for exploring sustainable development options at farm scale: a case study for vegetable farms in South Uruguay. Agricultural Systems 86:29-51.

31 Loyce, C. and Wery, J. 2006. Les outils des agronomes pour l'évaluation et la conception de systèmes de culture. L'agronomie aujourd'hui, QUAE éditions, 77-95.

32 Lançon, J., Wery, J., Rapidel, B., Angokaye, M., Gérardeaux, E., Gaborelc, C., Ballo, D., and Fadegnon, B. 2007. An improved methodology for integrated crop management systems. Agronomy of Sustainable Development 27:101-110.

33 Bockstaller, C., Guichard, L., Makowski, D., Aveline, A., Girardin, P., and Plantureux, S. 2008. Agri-environmental indicators to assess cropping and farming systems. A review. Agronomy of Sustainable Development 28:139-149.

34 Munier-Jolain, N.M., Faloya, V., Davaine, J.B., BijuDuval, L., Meunier, D., Martin, C., and Charles, R. 2004. A cropping system experiment for testing the principles of integrated weed management: first results. In Annales AFPP, XIIe colloque international sur la biologie des mauvaises herbes, Dijon. p. 147-156.

35 Chikowo, R., Faloya, V., Petit, S., and Munier-Jolain, N. 2009. Integrated weed management systems allow reduced reliance on herbicides and long-term weed control. Agriculture, Ecosystems and Environment 132:237-242.

36 Tonitto, C., David, M.B., Li, C.S., and Drinkwater, L.E. 2007. Application of the DNDC model to tile-drained Illinois agroecosystems: model comparison of conventional and diversified rotations. Nutrient Cycling in Agroecosystems 78:65-81.

37 Deike, S., Pallutt, B., Melander, B., Strassemeyer, J., and Christen, O. 2008. Long-term productivity and environmental effects of arable farming as affected by crop rotation, soil tillage intensity and strategy of pesticide use: A case-study of two long-term field experiments in Germany and Denmark. European Journal of Agronomy 29:191-199.

38 Nemecek, T., von Richthofen, J.F., Dubois, G., Casta, P., Charles, R., and Pahl, H. 2008. Environmental impacts of introducing grain legumes into European crop rotations. European Journal of Agronomy 28:380-393.

39 Fu, X.L., Zhang, H., and Jia, J.Z. 2009. Yield performance and resources use efficiency of winter wheat and summer maize in double late-cropping system. Acta Agronomica Sinica 35(9):1708-1714.

40 Gelfand, I., Snapp, S., and Robertson, G. 2010. Energy efficiency of conventional, organic, and alternative cropping systems for food and fuel at a site in the US Midwest. Environment Sciences Technology 44:40064011.

41 Freibauer, A., Rounsevell, M.D.A., Smith, P., and Verhagen, J. 2004. Carbon sequestration in the agricultural soils of Europe. Geoderma 122:1-23.

42 Mosier, A.R., Halvorson, A.D., Peterson, G.A., Robertson, G.P., and Sherrod, L. 2005. Measurement of net global warming potential in three agroecosystems. Nutrient Cycling in Agroecosystems 72:67-76.

43 Lehuger, S. 2009. Modélisation des bilans de gaz à effet de serre des agro-systèmes en Europe. Thèse de doctorat de l'Institut des Sciences et Industries du Vivant et de l'Environnement AgroParisTech. p. 184. 
44 Rochette, P. and Janzen, H. 2005. Towards a revised coefficient for estimating $\mathrm{N}_{2} \mathrm{O}$ emissions from legumes. Nutrient Cycling in Agroecosystems 73:171-179.

45 Pelster, D.E., Larouche, F., Rochette, P., Chantigny, M.H., Allaire, S., and Angers, D.A. 2011. N fertilization but not soil tillage affects nitrous oxide emissions from a clay loam soil under a maize-soybean rotation. Soil and Tillage Research 115-116:16-26.

46 Debaeke, P., Munier-Jolain, N., Bertrand, M., Guichard, L., Nolot, J.M., Faloya, V., and Saulas, P. 2009. Iterative design and evaluation of rule-based cropping systems: methodology and case studies. Agronomy of Sustainable Development 29:73-86.

47 Coleman, K. and Jenkinson, D.S. 1999. A model for the turnover of carbon in soil; Model description and windows users guide, IACR - Rothamsted. p. 47.

48 Andriulo, A., Mary, B., and Guerif, J. 1999. Modelling soil carbon dynamic with various cropping sequences on the rolling pampas. Agronomie 19:365-379.

49 Van Groenigen, K.J., Hastings, A., Forristal, D., Jones, M., and Smith, P. 2011. Soil C storage as affected by tillage and straw management: An assessment using field measurements and model predictions. Agriculture, Ecosystems and Environment 140:218-225.

50 GES'TIM 2010. Ministère de l'agriculture, de l'alimentation, de la pêche, de la ruralité et de l'aménagement du territoire. Réf. 0933103.

51 Intergovernmental Panel on Climate Change. Climate Change 2007. The Physical Science Basis. Cambridge University Press, UK. p. 1009.

52 Leteinturier, B., Herman, J.L., de Longueville, F., Quintin, L., and Oger, R. 2006. Adaptation of a crop sequence indicator based on a land parcel management system. Agriculture, Ecosystems and Environment 112 (2006):324-334.

53 Smith, P., Smith, J., Powlson, D., McGill, W., Arah, J., Chertov, O., Coleman, K., Frnko, U., Frolking, S., Jenkinson, D., Jensen, L., Kelly, R., Klein-Gunnewiek, H., Komarov, A., Li, C., Molina, J., Mueller, T., Parton, W., Thornley, J., and Whitmore, A. 1997. A comparison of the performance of nine soil organic matter models using datasets from seven long-term experiments. Geoderma 81:153-225.

54 Bockstaller, C., Guichard, L., Keichinger, O., Girardin, P., Galan, M.B., and Gaillard, G. 2009. Comparison of methods to assess the sustainability of agricultural systems. A review. Agronomy of Sustainable Development 29:223-235.

55 Liu, D.L., Chan, K.Y., Conyers, M.K., Li, G., and Poile, G.J. 2011. Simulation of soil organic carbon dynamics under different pasture managements using the Roth C carbon model. Geoderma 165:69-77.

56 Cerri, C., Easter, M., Paustian, K., Killian, K., Coleman, K., Bernoux, M., Falloon, P., Powlson, D., Batjes, N., Milne, E., and Cerri, C.C. 2007. Simulating SOC changes in 11 land use change chronosequences from the Brazilian Amazon with Roth $\mathrm{C}$ and Century models. Agriculture, Ecosystems and Environment 122(1):46-57.

57 Agreste, an agricultural statistical service of the French government. Available at Web site http://agreste.agriculture. gouv.fr/ (accessed August 22, 2014).

58 Riley, H., Hoel, B.O., and Kristoffersen, A.Ø. 2012. Economic and environmental optimization of nitrogen fertilizer recommendations for cereals in Norway. Acta Agriculturae Scandinavica, Section B, Soil and Plant Science 62(5):387-400.

59 Jeuffroy, M.H., Baranger, E., Carrouée, B., de Chezelles, E., Gosme, M., Henault, C., Schneider, A., and Cellier, P. 2013. Nitrous oxide emissions from crop rotations including wheat, oilseed rape and dry peas. Biogeosciences 10:17871797.

60 Zentner, R.P., Lafond, G.P., Derksen, D.A., Nagyd, C.N., Wall, D.D., and May, W.E. 2004. Effects of tillage method and crop rotation on non-renewable energy use efficiency for a thin Black Chernozem in the Canadian Prairies. Soil and Tillage Research 77:125-136.

61 Nowacki, W. 2008. Comparison of profitability of potato cultivation in organic and, integrated farming systems. Progress in Plant Protection 48(4):1526-1534.

62 Blazy, J.M., Ozier-Lafontaine, A., Doré, T., Thomas, A., and Wery, J. 2009. A methodological framework that accounts for farm diversity in the prototyping of crop management systems. Application to banana-based systems in Guadeloupe. Agricultural Systems 101:30-41.

63 Coulter, J.A., Sheaffer, C.C., Wyse, D.L., Haar, M.J., Porter, P.M., Quiring, S.R., and Klossner, L.D. 2011. Agronomic performance of cropping systems with contrasting crop rotations and external inputs. Agronomy Journal 103(1):182.

64 Moreno, M., Lacasta, C., Meco, R., and Moreno, C. 2011. Rainfed crop energy balance of different farming systems and crop rotations in a semi-arid environment: Results of a long-term trial. Soil and Tillage Research 114(1):18-27.

65 Feiza, V., Feiziene, D., Auskalnis, A., and Kadziene, G. 2010. Sustainable tillage: results from long-term field experiments on Cambisol. Zemdirbyste (Agriculture) 97 (2):3-14.

66 Baturo, A. 2007. Effect of organic system on spring barley stem base health in, comparison with integrated and conventional farming. Journal of Plant Protection Research 47(2):167-178.

67 Klimekova, M. and Lehocka, Z. 2009. Comparison of yields and qualitative characters of spring barley grown, after three preceding crops in an organic farming system in the years, 2003-2008. Agronomy Research 7(Special Issue):335-340.

68 Liebman, M., Gibson, L., Sundberg, D., Heggenstaller, A., Westerman, P., Chase, C., Hartzler, R., Menalled, H., Davis, M., and Dixon, P. 2008. Agronomic and economic performance characteristics of conventional and low-external-input cropping systems in the Central Corn Belt. Agronomy Journal 100(3):600-610.

69 Cavigelli, M.A., Hima, B.L., Hanson, J.C., Teasdale, J.R., Conklin, A.E., and Lu, Y. 2009. Long-term economic performance of organic and conventional field crops in the mid-Atlantic region. Renewable Agriculture and Food Systems 24(2):102-119.

70 Le Gal, P.Y., Dugué, P., Faure, G., and Novak, S. 2011. How does research address the design of innovative agricultural production systems at the farm level? A review Agricultural Systems 104:714-728.

71 Stoorvogel, J.J., Bouma, J., and Orlich, R.A. 2004. Participatory research for systems analysis: Prototyping for a Costa Rican banana plantation. Agronomy Journal 96 (2):323-336. 
72 Shili-Touzi, I., de Tourdonnet, S., Nciri, R., Le Floch, D., Saulas, P., and Doré, T. (submitted). Is it possible to manage competition between wheat and alfalfa grown as a service plant in an intercropping system in temperate conditions? Agriculture, Ecosystems and Environment.
73 Alletto, L., Coquet, Y., and Roger-Estrade, J. 2010. Two-dimensional spatial variation of soil physical properties in two tillage systems. Soil Use and Management 26:432444. 